\title{
Becoming Ryan: Lines of flight from majoritarian understandings of masculinity through a high school reading and mentoring program. A story of possibility
}

Mandy Rogers

School of Education and Professional Studies, Griffith University, Australia.

Leonie Rowan (corresponding author)

Griffith Institute of Educational Research, Griffith University, Australia.

Email: l.rowan@griffith.edu.au Phone: 0755528144 Fax:07 5558599

Rachel Walker

School of Education and Professional Studies, Griffith University, Australia.

\begin{abstract}
Within literature relating to the broad field of boys' education attention is regularly drawn to the significant difference between essentialist and anti-essentialist accounts of "the boy problem" and the limitations of gender-based educational reforms which rely upon deterministic notions of what boys are 'really' like and, by extension, what they 'really' need. While these deterministic interventions have been widely critiqued in academic literature they nevertheless continue to dominate school and media based discussions about how to best support alienated, disengaged and at risk boys. This raises questions about the extent to which anti-essentialist approaches can be made more accessible and meaningful to teachers in schools. It further suggests the value of developing detailed accounts of real world interventions that have had a demonstrably positive impact upon the boys involved without reinforcing essentialist notions of masculinity. Adopting an attitude of "educated hope" (Giroux, 2003) and drawing upon the resources of Gilles Deleuze and Felix Guattari (1987), this paper examines one such case of anti-essentialist reform involving three Australian schools. It explores one particular boy's experience of an intervention known as Boys with Books and argues that Ryan's journey can be conceptualised as a line of flight away from traditional forms of masculinity: a journey in progress that has impacted positively upon his relationships with peers and teachers and changed his beliefs about his possible future options. The paper, therefore, illustrates the capacity for teachers and schools to display anti-essentialist understandings about masculinity while responding in practical and 'do-able' ways to the needs of at risk, alienated and underperforming boys in schools.
\end{abstract}

Keywords Boys and school; masculinity; gender innovations; feminist rhizomatics; anti-essentialist gender reform 


\section{Introduction}

Literature relating to the broad field of boys' education has provided detailed and compelling pictures of how individual boys can struggle to negotiate the (often) competing discourses of schooling, masculinity, culture and class and the toll that this struggle can take (Archer and Yamashita, 2003; Gilbert and Gilbert, 1998; Kehler, 2007; Mac an Ghaill, 1994). This same literature has increasingly explored the challenges associated with attempts to disrupt long standing, powerful and limiting understandings of what it means to be a 'real' boy in western education systems (Alloway et al., 2002; Collins et al., 2000; Hayes et al., 2006; Keddie, 2003). Explorations of educational interventions focused on boys' education have consistently drawn attention to the fundamental differences between essentialist and anti-essentialist perspectives on boys and the inherent limitations of those programs which are based upon deterministic notions of what boys are 'really' like and, by extension, what they 'really’ need (Lingard and Douglas, 1999; Martino et al., 2004). Many such interventions ultimately prove to be counter-productive because they "invariably normalize, reinforce and leave unquestioned a narrow and often unproblematic version of masculinity” (Keddie, 2008, p. 100).

But while the limitations of deterministic and biologically based approaches to boys' education have been widely critiqued within scholarly publications they nevertheless continue to dominate school and media-based discussions about how to best support alienated, disengaged and/or 'at risk' boys.

The persistent appeal of the essentialist mindset to those working in schools raises a number of points for those committed to the pursuit of gender justice (Keddie, 2005) in education. First it is clear that teachers' "threshold knowledge” (Martino et al., 2004, p. 435) has a direct impact upon how they conceptualise and enact gender-based educational reform (Rowan and Lynch, 2011). As Major and Santoro (Major and Santoro, 2014, p. 70) argue "teachers may be largely unaware of how they contribute to positioning boys and girls in particular ways in the classroom”. From this perspective, if popular and powerful representations of boys are ever going to be disrupted teachers need to be provided with ongoing opportunities (in pre-service training and professional development) to identify and analyse the understandings of gender and masculinity that inform their educational practice (Major and Santoro, 2014). As Keddie (2008, p. 100) argues, research based knowledges have a key role to play in developing among teachers the essential capacity for critically reflecting upon the nature and potential effects of the 'reform' strategies they seek to employ.

Teacher knowledge, however, has many dimensions and in this paper we argue that any commitment to the development of educators' gender-based knowledges (in pre-service or professional development programs) needs to reflect an appreciation of each of the following points. First, while it is not always the main focus of scholarly publications investigating boys' education, literature focused on educators, gender and educational contexts has often identified a degree of resistance on the part of teachers when it comes to engagement with theoretical resources associated with contemporary perspectives on gender, masculinity and/or feminism (Jones, 1997; Titus, 2000). This resistance has sometimes been linked to the difficulties of challenging longstanding, familiar and culturally endorsed beliefs about gender and gendered behaviour (particularly when many of us gain pleasure from allegiance to these 
beliefs). Resistance has also been linked to what may be seen as the alienating or unfamiliar nature of some of the key theoretical resources: particularly those that draw upon feminist post-structuralism (Jones, 1997).

Importantly, however, the reluctance of some teachers to engage with research relating to gender justice has also been connected to what might be realistically described as the confronting and depressing nature of gender and education as a field of study. Literature is filled with studies that document the ongoing (and often horrifying) ways in which gender impacts negatively upon the educational and social pathways of diverse boys and girls. Similarly well documented is the persistent failure of schools (and teachers) to disrupt or transform patterns of alienation, marginalisation and disengagement. While this literature is invaluable to the broad project of gender-based educational reform it is not without its risks. As early as 1994 Kenway, Willis, Blackmore \& Rennie (1994, p. 208) advocated the need for research into girls' education that was able to make hope practical rather than despair convincing. This point remains relevant to those conducting research into the educational experiences of boys. Stories about the 'failure' of various attempts at gender reform have a valuable role to play in improving educators' knowledge base. So, too, do stories that remind us of the possibilities that exist for change.

The third point we'd like to emphasis here, therefore, is the importance of gender-based scholarship that proceeds from an attitude of "educated hope” a position which, according to Henry Giroux, provides a vocabulary for challenging the presupposition that there are no workable, sustainable alternatives to the existing social order” (2003, n.p.). The need to balance critique of what is, with an optimistic recognition of what might be is also a strong theme within much contemporary feminist philosophy. Rosi Braidotti, for example, emphasises the political importance of the imagination: of working to map not only the persistence of traditional, bounded understandings of what it means to be a woman (or a man), but highlighting as well the possibilities that exist for the emergence of new and transformative figurations of gender (Braidotti, 1994).

Together these three points suggest that while it remains absolutely crucial for researchers and practitioners to continue to map the ways in which meanings attached to differences such as gender, language, sexuality and culture shape the educational and social experiences of diverse boys and girls (and for this to be the basis of ongoing professional development with classroom teachers), this work must be accompanied by stories which speak to the issue of hope. Many valuable stories of transformation emerge as the result of deliberate, explicitly theorised educational interventions (such as those based on the important practice-oriented and anti-essentialist frameworks articulated by authors such as Davies (1994), Major and Santoro (2014) and Keddie (2005). These stories demonstrate the fluid and multiple nature of subjectivity and contest the idea that there is any single, unified, 'natural' version of masculinity to which boys should aspire. Equally important are interventions that emerge as the result of optimistic, purposeful decisions by individual teachers to explore opportunities for boys to transgress and exceed some of the limitations of the forms of masculinity they may be most familiar 
with. These interventions demonstrate teachers' power to make a difference: power which rests upon their "being able to imagine otherwise in order to act in other ways" (Giroux, 2003, n.p.).

Drawing upon the resources offered by Gilles Deleuze and Felix Guatarri (1987), this paper provides one account of an imaginative, teacher-led intervention that can be understood as anti-essentialist in its approach to boys and educational reform as evidenced by the freedom it offers the participants to engage with multiple ways of performing the role of boy-in-school. In documenting this example we embrace the position of “Deleuzian affirmation” outlined by Elizabeth St.Pierre. Drawing upon John Rajchman and Deleuze, St. Pierre argues that such a perspective “"requires a belief or trust in the world and what may yet transpire in it, beyond what we are warranted to assert' (p. 76)... 'a belief of the future, in the future’” (cited in St.Pierre, 2004, p. 287).

From this position we seek to demonstrate a simple but politically powerful point: that despite the well documented persistence of narrow and limiting understandings of masculinity (and the impact these have on the lives and work of teachers and students) it is nevertheless still possible for teachers and schools to create environments within which masculinity is perceived as multiple, plural and open to negotiation: thus as fundamentally anti-essentialist in that they are not constrained by binaristic logic, or oppositional thinking. The story we develop gives additional weight to the arguments of the large number of scholars advocating for anti-essentialist responses to diverse boys in school as it helps to demonstrate the important point that schools are not forever doomed to remain sites of oppression. They can be sites of resistance, transformation and hope.

The intervention that we will discuss is called Boys with Books and some brief contextual information is important here. Boys with Books is a partnership between three neighbouring, public schools in a highly populated area of Queensland. The partnership involves a high school, a primary school and an alternate education setting (AES), which caters for a small number of students in the early years of school who have been temporarily excluded from their regular school because of behavioural issues. All three schools are characterised by significant cultural diversity (with notable populations of Samoan, Pasifica and Maori students) and have a large number of students from low socio-economic backgrounds.

The project was developed by the high school's Deputy Principal (Andrew) who continues to coordinate its operation. Andrew works in collaboration with one of the high school's English teachers, Elly, who now takes responsibility for the day-to-day running of the program. Each year Andrew and Elly select approximately 12 high school boys (between the ages of 12 and 18) to act as reading mentors for two different groups of primary students. The first group are from the neighbouring primary school. These are boys in year 2 of school (between 7 and 9 years old) who have been selected for participation by their teachers, generally because they are underperforming in literacy. The second group are the boys currently attending the AES. This small group (approximately 5) are also in the early years of school: aged between 5 and 7. 
The high school boys travel to these two different sites approximately once a week throughout most of the school year. Before the visits begin, the mentors are given some basic instruction on how to interact with the younger boys (for example strategies to suggest when helping the younger boys decode the text). During the visits the mentors spend approximately forty-five minutes in one-on-one reading situations with the younger boys who select books to share from boxes provided by their regular classroom teachers. While the interactions are supervised by Elly (and a teacher from the primary school or AES depending on the venue) each mentor interacts with his buddy in his own way. There are no scripts to follow and no rigid rules. The only requirement is reading.

This paper argues that Boys with Books has had a significant impact upon some of the high school participants: the mentors who read to and with the younger boys. We argue that what looks like a simple intervention achieved the very complex task of creating spaces for the participating boys to move from seeing themselves as naturally bad students (in terms of either their behaviour or their achievement) with limited futures to thinking about themselves (and their schooling and their futures) in more positive and optimistic ways. To illustrate the impact of the intervention we focus on the experience of one particular boy—a boy we call Ryan—and map his movement from despair, anger and alienation towards confidence, self-control and hope.

In order to fully explore the significance of this movement it is necessary to locate the research within the broader history of gender-based educational reforms. The key aim of the literature review that follows, therefore, is to provide the background necessary to allow us to justify the claims we make (above and below) about the significance of the Boys with Books initiative.

\section{Background and Literature}

Research focusing on boys' education is diverse and the focus of debate has undergone many shifts. The early mass mediated catch cry "what about the boys?” motivated numerous attempts to quantify the extent of any gap that might exist between the achievements of girls and boys (Collins et al. 2000; Organisation for Economic Co-operation and Development 2004). Early efforts to demonstrate that boys were the new disadvantaged often argued that schools had focused for too long on the needs of girls while failing to value the essential qualities of boys (Gurian, 2001; Sommers, 2000a).

These early crisis based and often emotionally charged debates were paralleled by more measured (and, commonly, less public) attempts to acknowledge that it was not necessary for educators to choose between the needs of boys and girls in a competing victims framework. Rather, it was possible to simultaneously believe that there were ongoing issues relating to the educational experiences and achievements of girls and boys (Newkirk, 2000). Thus, without denying the possibility that girls’ education still had serious issues to address (and often actively pursuing a pro-feminist agenda), literature unpacking claims about boys soon began to reveal issues of concern including patterns of poor or under-achievement in areas relating to literacy generally and reading particularly (Alloway and 
Dalley-Trim, 2006; Organisation for Economic Co-operation and Development, 2004; Rothman and McMillan, 2003).

Studies in diverse locations and contexts further suggested that boys were more likely than girls to be linked to classroom disruptions, school avoidance, suspension/exclusion and high risk behaviours (Collins et al., 2000). And while men (as a group) continued to dominate high paying, high prestige professions, boys were more likely than girls to leave school before completing year 12 (Rowan et al., 2002). As a result 'boys' (who were sometimes still spoken about as a largely undifferentiated group) were seen to be at greater risk than girls of periods of unemployment and underemployment, poor physical and mental health, problematic and unstable relationships and displays of dangerous behaviour.

By the mid 2000s more and more detailed readings of the constructed and embodied nature of masculinity increasingly demonstrated that gender was not a sufficient category to explain the variety of boys’ experiences at school where they negotiate “multiple masculinities” (Connell, 1996, p. 208). With researchers addressing the question “which boys?” (Collins et al., 2000, p. 60) attention was increasingly focused on the ways in which gender intersects with factors such as sexuality, class, cultural background or geographical location to create embodied experiences and particular patterns of risk (Mac an Ghaill, 1994; Martino and Pallotta-Chiarolli, 2005; White, 2007; Major and Santoro, 2014).

Cognisant of this body of scholarship diverse researchers associated with anti-essentialist frameworks (such as post-structuralism, post-colonialism or queer theory for example) have advocated for intervention projects that:

- Understand masculinity in fundamentally anti-essentialist ways; recognising masculinities as multiple; as culturally and socially produced (rather than biologically determined) and thus open to both critique and change

- Acknowledge that all definitions of masculinity are fundamentally connected to definitions of femininity. Thus critiques or celebrations of dominant masculinities also impact upon understandings of femininity

- Recognise that discourses of masculinity always intersect with discourses of race, class, socioeconomics and sexuality and that gender cannot therefore be studied in isolation

- Appreciate the fundamental interconnection between school and wider social contexts

- Understand the ways in which particular understandings of masculinity are in oppositional relationships with the skills, abilities and behaviours most commonly valued in school contexts

- Value the creation of educational environments which recognise and respond to the diversity within and between groups of boys and girls 
- Value the sharing of stories about how the power of hegemonic masculinities and dominant discourses about masculinity have been interrupted, contested, denaturalised by diverse boys (and/or teachers) in diverse locations

Each of these commitments are underpinned by the belief, articulated by authors such as Keddie (2008, p. 150) that "schools can and must make a difference in creating more just, more equitable and more peaceful societies". But as we have argued earlier, the persistence of counterproductive interventions suggests that debates about boys' education require a research-based body of evidence that will serve as a "platform from which to implement a reform agenda in boys' education that is committed to gender justice as opposed to a recuperative masculinity politics” (Keddie, 2008, p. 150). This body of evidence must recognise and challenge the persistent appeal of essentialist frameworks based upon very narrow 'truth claims' about masculinity that continue to dominate gender-based reforms in school (Martino et al., 2009, p. xx). At the same time, however, it must provide evidence of the legitimacy of a position of hope.

This paper, therefore, argues that destabilising naturalised truth claims about boys is facilitated by the ability to provide detailed stories about small scale educational interventions that do not end up in the dead-end territories so commonly linked to reform projects based upon simplistic understandings of boys' essential interests, abilities or needs. We believe that the complex and multifaceted work of critiquing and contesting longstanding and powerful understandings of masculinity and femininity necessitates a commitment to both the ongoing identification of gendered practices and the celebration of the moments and spaces where individual boys are able to exceed some of the limitations associated with hegemonic, mainstream or normative masculinities.

Making use of the work of Deleuze and Guattari (1987) the paper explores the ways in which the Boys with Books project allowed boys to explore lines of flight away from mainstream or molar, majoritarian understandings of masculinity towards molecular, minoritarian subjectivities which can be seen as antiessentialist because of the spaces they open up for the participants to engage multiple ways of being a boy.

\section{Boys with Books}

In its earliest form the Boys with Books program was a mentoring initiative designed to try and improve the literacy engagement of boys at high school and primary school. The mentor/role model approach is a fairly common feature within school-based boys and reading interventions and programs often involve attempts to pair the younger children with boys (or teachers or high profile public personalities such as sports stars) who are both good at reading and good at "being boys" (Martino et al., 2004, p. 435). That is to say, programs often reflect a desire to capitalise on the cultural capital of a particular boy/man (capital that may be attached to his sporting success, his academic success, his personal appearance, his overall popularity) by using it to help sell reading to younger boys who may previously 
have regarded this kind of activity (consciously or otherwise) as uncool or unmanly (Brozo, 2006; Ontario Ministry of Education, n.d.; Taylor and Lorimer, 2002/2003).

Many examples of mentoring programs have been critiqued because of underlying essentialist, sexist and racist attitudes. Common criticisms include the belief that male-mentoring is necessary in the first place because of the overly feminised nature of schools; that women lack the ability to fully understand and support boys; that men—any men—have an automatic, biologically related potential to impact positively on boys; that men teach in fundamentally unique ways and thus better meet the needs of boys; and that learning to be a 'real man' is a process that demands male role models. These criticisms have made many educators understandably wary about the use of mentoring programs within boys' education. Throughout this paper we use the words 'mentoring' and 'role models' to talk about the Boys with Books program because these are the words that are commonly used by the project's coordinator, Andrew. Nevertheless, we do not believe that this particular case of mentoring is based upon the essentialist ideologies so often critiqued. There are a number of reasons why we believe the project can be understood this way.

First, in selecting participants the program did not seek to celebrate any particular, 'normal' or celebrated version of masculinity to which the boys (be they young or old) were expected to aspire. Consistent with common features of male mentoring approaches, some of the boys who were chosen to act as mentors were indeed selected because of their high status, popularity and image of 'coolness'. In these cases it was generally felt that the presence of that 'type' of boy would do something positive for the image of the program: even if some of the so-called sports stars were not, themselves, good readers. At the same time, however, many of the other participants were chosen to act as mentors, not because of their good reputation but, rather, in spite of pretty well established 'bad' reputations. Some of these boys were at risk of educational alienation, failure or, in some extreme cases, actual exclusion from the school. In other words, they were chosen not only (or primarily) because of what they would bring to the program, but also out of a hope that the program could bring something to them. The key difference between this approach and many other mentoring approaches is that the 'at risk' boys were not assigned the role of 'boy-to-be-mentored'; rather, they were trusted to do the active work of mentoring. As a result the program, in 2012, was a mix involving "not just the rugby league players, not just the academics, not just the complex kids, not just the rejected” (Andrew, 2011).

Second, the mentoring program had aims that went well beyond trying to give boys specific role models they would do well to emulate. Although the program was initially conceptualised as an initiative that might improve the mentees’ attitudes towards reading, over time it evolved into a program with a much wider set of goals. Indeed, the program was conceptualised by staff in ways that resonate with three of the four dimensions of productive pedagogy which Keddie (2005, pp. 92-93) has linked to the pursuit of gender justice in schools: connectedness, supportive environments and recognition of difference. As the discussion below will demonstrate, the program did not try to identify and support any single way of 'being a boy'. Rather, emphasis was placed on opportunities for 
the participants to develop new relationships (with each other and with staff) and a positive sense of self, through interactions characterised by respectful relationships. Staff conceptualised the program as a space that also allowed both the younger and the older boys to experience school differently: to feel recognised, valued, supported: a place to experience success.

In Andrew's words:

The priority of this initiative is the mentoring of a group of boys with each other across all aspects of the school...We put them all together and then they bond, they become this little team and it's just fabulous... it's about boys helping boys and developing each other with its context in reading.

Throughout 2011 and 2012 three researchers (2 honours students and their supervisor) conducted a detailed study of the Boys with Books initiative. While each student ultimately completed an individual analysis of the data, our shared goal as researchers was to investigate the extent to which Andrew's belief that Boys with Books could help boys “across all aspects of the school” was justified. We were particularly conscious (as acknowledged above) that many similar projects rely upon essentialist notions of what a boy is, and how a boy should behave and that a successful outcome might be the boys developing renewed confidence in the 'authentic' and desirable nature of narrow, socially prescribed ways of performing masculinity. We were further concerned that the program may seek to celebrate very particular types of boys (in terms of cultural background, sexuality or socio-economics) and that the sense of belonging the program sought to cultivate might be based upon familiar hierarchies which value some performances of masculinity over others. However our early observations of the program made us cautiously optimistic that this program was able to resist the lure of essentialist understandings of what boys 'are' and thus what boys 'need'. To test out our optimism we sought to identify how the boys (and their teachers, parents and peers) described the impact of the program on such things as their confidence, attitude towards schools, attitudes towards others, attitudes towards the future. As we became more and more familiar with the project participants, and as we learned more and more about the stories of each individual boy, we were increasingly drawn towards the analytical resources offered by Gilles Deleuze and Felix Guattari (1987) to help us explore the experiences of project participants and, particularly, the ways in which it provides a language to discuss the different ways in which the participants were able to perform the role of 'boy'.

In the next sections of the paper, therefore, we will discuss the Boys with Books program by focusing on the particular experiences of one boy called Ryan. In exploring Ryan's story our goal is to identify the way in which he contributes to the desire outlined above to make hope "practical" (Kenway et al., 1994, p. 208) by demonstrating the potential for schools to provide boys with space to depart from what were (in this specific context) the mainstream, familiar, dominant ways of 'being a boy' (with all their associated risks) and to embark on a process of becoming: a process that allows Ryan to be more than one thing; to be a boy in more than one way. Before moving specifically to discuss Ryan's line of 
flight it is necessary to provide some more detail about the Deleuzian concepts used to structure the analysis.

\section{Theoretical Framework}

As noted above, Deleuze and Guatarri's theory of becoming resonates with one of the central tenants of post-structural feminism and allied anti-essentialist theories: that what is commonly described as an individual's identity, or sense of self—a sense that is linked not only to internal thoughts or desires but also to behaviours, relationships and interactions with others-is neither biologically determined nor completely socially controlled but rather the product of constant negotiation between an individual and social and cultural discourses.

From this perspective "the individual is always the site of conflicting forms of subjectivity" (Weedon, 1987, p. 33). At any single moment in any particular location an individual may be negotiating multiple discourses that tell them what it 'really' means to be a natural/normal member of a particular group. A young boy who is raised to believe that being a 'real' boy-at-home is about being loud, confident, tough and active, for example, may find himself challenged by a school context that tells him that being a good learner is about being quiet, deferential and obedient. This boy must negotiate these different messages in order to perform the new role of boy-in-school. A different boy raised to see himself as responsible for those in his family may also struggle when faced with the individualistic and competitive nature of school-based assessment.

This representation of identity as fluid, rather than fixed, and performed rather than given, is central to Deleuze and Guattari’s theory of becoming. Within the Deleuzian framework the subject is:

not an entity or thing, or a relation between mind (interior) and body (exterior); instead, it must be understood as a series of flows, energies, movements, capacities, a series of fragments or segments capable of being linked together in ways other than those which congeal it into an identity (Grosz, 1993, p. 167)

Thus rather than always or already being something (anything: male, female, masculine, feminine, good boy, bad boy) individuals can be understood as in a state of becoming: becoming-other. The Deleuzian idea of becoming rests upon two claims: first, as already noted, that each individual confronts dominant and powerful understandings about what it means to 'be' a particular person (to have a particular body) and second, that despite the power of these normative understandings it remains possible for an individual to move. These two key points are reflected in a range of additional concepts that are also central to the Deleuzian framework. A first distinction is drawn between the arboreal and the rhizomatic. Arboreal refers to hierarchical structures that function on binary logic and "impose limited and regulated connections between their components” (Bogue, 2002, p. 107). A rhizome, by contrast, is a horizontal structure that grows in multiple directions across the ground; it operates across territories. As Deleuze and Guattari write: “unlike trees or their roots, the rhizome connects any point 
to any other point, and its traits are not necessarily linked to traits of the same nature” (Deleuze and Guattari, 1987, p. 21). While arboreal structures maintain hierarchy and existing systems of power the rhizome works against singular representations of 'what is' it “operates by variation, expansion, conquest, capture, offshoots” an “accented, non-hierarchical, non-signifying system” (Deleuze and Guattari, 1987, p. 21).

Deleuze and Guattari expand on the rhizomatic image through reference to minority and molecular positions and majoritarian or molar understandings. A majoritarian position is a state of domination: a state that reflects, not a statistical majority but ease of access to and familiarity with the operation of social or political power. According to MacCormack "the majoritarian is not a self-evident or a priori position, rather it is the particularity of a moment, however extended or brief, where a specific form of body is dominant” (2001, p. 2). Nevertheless, the majoritarian is arboreal and molar - its parameters are established and it does not "make new and strange connections, or exist transformatively in time, but rather fulfil[s] a certain form of subjectivity fixed in space” (MacCormack, 2001, p. 2). Molarity, in this context, is the mode of being (dominant) rather than becoming (other).

By contrast, a minoritarian position can be thought of as a multi-armed chain of molecules; a group collection "whose connections are not pre-determined or predictable but forge based on (often divergent) need, desire and chance” (MacCormack, 2001, p. 2). Molecular entities are "shape-shifting from one moment to the next” (MacCormack, 2001, p. 2) and thus work to resist arboreal, molar, majoritarian ways of being.

The tension between the molar and molecular, rhizomatic and arboreal, is played out in an ongoing process of deterritorialization and reterritorialization. According to Deleuze and Parnet (1987), individuals and groups are made up of 'lines': molar lines of rigid segmentarity (drawing boundaries around what is seen as 'natural' and 'normal' behaviours for boys) and "supple lines of segmentarity made from molecular fluxes, and lines of flight that cut right across things and launch us into the unknown” (Deleuze and Parnet, 1987, pp. 124-125). Lines of flight, in this context, are journeys that transgress familiar, coded, molar ways of being in the world, and chart molecular, unbounded, connections: they are acts of deterritorialization.

When used to consider issues relating to masculinity in schools, this Deleuzian framework helps highlight the existence of what we have referred to above as hegemonic and subordinate masculinities and the spaces for boys to perform their masculinity in diverse, non-traditional ways. In relation to the Boys with Books project it encourages us to look for lines of flight away from the familiar, dominant, majoritarian ways of 'being a boy' towards less familiar subjectivities. In framing our analysis of the project we asked a range of questions including:

- To what extent and in what ways do the mentors within Boys with Books project traverse molar, majoritarian understandings of masculinity in lines of flight toward molecular, minoritarian positions? 
- To what extent are these lines of flight reflected in the ways the boys relate to each other, to teachers, to family and to school?

To answer these questions we drew upon diverse forms of data: observations, focus groups and interviews. Data collection took place throughout 2011 and 2012 and involved:

- An interview with the coordinator and founder of the Boys with Books initiative: Andrew

- An interview with the teacher who travelled with the boys to each of the sessions: Elly

- Interviews with five teachers who were either present during a Boys with Books session, or who had involvement with one of the mentors

- Interviews with eleven of the current high school mentors

- Interviews with two former (graduated) mentors

- Interviews with the mothers of two of the mentors.

- One focus group session with ten high school students about the Boys with Books project

- Five observations of Boys with Books mentoring sessions at the alternative education setting (each one up to forty-five minutes in length)

- Eight observations of Boys with Books mentoring sessions at the primary school setting (each one up to 45 minutes in length)

As noted in the introduction, this paper seeks to contribute to a broader project of mapping the possibilities that exist (within most school systems) for projects focused on boy's education to operate in anti-essentialist ways. With a commitment to documenting the ways in which interventions in 'real world' schools can contest narrow, limiting, hegemonic understandings of masculinity-in-school by facilitating and validate individual boy's rhizomatic lines of flight we turn now to our exploration of the impact of Boys with Books on Ryan.

\section{Becoming Ryan: reflecting back}

In 2012 Ryan was a student in Year 10 at our State High School. A Polynesian boy (and a member of a cultural minority at this school) Ryan at 15 years old stood 180 centimetres tall. He was the only boy who had been involved in the Boys with Books program for the duration of is three year operation and is an example of a boy who was invited into the program as a mentor, not because of the 'positive' example he had already provided to other boys, but rather because of his marginalised position within the school community. His mother, the school's Deputy Principal, Andrew, and the learning support teacher provide powerful descriptions of what Ryan was like at the time he was asked to join Boys with Books in 2009.

Asked to describe the relationship between himself and Ryan before he joined the program, the Deputy Principal made the following comments:

it was nearly a war zone between the two of us - he was a Grade 8 big boy - almost the same size as he is now - he was that size kind of in Grade 8 and was very intimidating to 
our staff - particularly our male staff - so there was a lot of confrontation with him and our staff and particularly me..

He goes on to say:

He was very aggressive - aggressive to the point that he would have - he was in teacher's faces - so it wasn’t just another student...it wasn’t just with students - if a teacher said the wrong thing or if a teacher approached him in the wrong way he would be, you know, in the teacher's face as well.

Ryan's mother further notes that "He was always in trouble, always in detention and suspended... I don’t know how many times...”

The interview with Ryan's mother provided some poignant background information about Ryan and the factors that combined to see him positioned so quickly, in a new school, as a magnet for trouble:

When we first arrived in Australia, we have been here 3 years... Ryan had lost siblings so he had a bit of a behaviour problem...he didn't know how to deal with it - he struggled to cope with it. So when we came over here because of his size, how big he is, he got picked on a lot. Kids wanted to pick on him and fight him and see if they could beat him up and all that. School he found really hard. He hated people yelling at him he used to sort of just cringe so he found it very hard mentally and physically because of how big he is.

Ryan's mother also identified a link between Ryan's own reading problems and the death of his family members:

...he found it very hard to read after losing his siblings - he kind of reverted to being a younger child because he didn’t want to grow up because couldn’t understand why they had been taken so young and why he lost his family so he reverted to being a child and all his reading ability and everything just went out of the window... You know because we used to play reading games like how do you spell ‘car' and he couldn’t even read or spell the word 'car' but before his sister and brother passed away he was fine...

This background information helps to explain the comments made about Ryan by his Learning Support teacher:

[Before joining the program]...He was very resistant about doing anything...he certainly wouldn't read out loud when we had things to read. His written work was atrocious and he was totally negative about being in the classroom. His behaviour showed that because he did do things to ...get thrown out of class. 
Ryan's story is similar to so many others told about the forms of masculinity displayed by alienated, working class, culturally diverse boys in suburban Australian schools (Griffin, 1994). He was a boy known for his aggression and anger; a boy with a supportive family but an inability to 'do' school in any way that was able to break a cycle of punishment; a boy with limited chance of completing his secondary education; a boy with a limited set of options.

It is easy to imagine Ryan being dealt with by the school in ways that would ultimately reinforce molar, majoritarian essentialist understandings of what it means to 'be' a working class, Polynesian, illiterate boy, practicing a form of masculinity that was expected (and in some ways demanded by his peers) but simultaneously devalued by other boys and by the school administration. Indeed, prior to his involvement in the Boys with Books program the gap between Ryan's performance of masculinity and what the school was able to accept was so wide that Deputy Principal Andrew had little hope that Ryan would be able to remain in the school. As he said "I thought he was definitely going to be an exclusion - I didn't think that the school could put up with the physical intimidation from him - we were going to have to let him go.”

This brings us to a key moment in Ryan's school life. Dominant discourses about boys like Ryan suggest that exclusion is almost inevitable. This is part of an arboreal understanding of what it means to 'be' someone who looks and feels and acts like Ryan: a story where low socio-economics, poor literacy skills, family trauma and displays of aggression are seen both as tragic and regrettable but still linked to futures that are inevitable. However, rather than staying within this arboreal framework, Ryan's Deputy Principal was able to imagine an alternative future for Ryan. Rather then interpreting Ryan's behaviours as evidence of who he 'really' and 'essentially' was or could 'be' Andrew adopted an antiessentialist perspective that allowed him to conceptualise the possibility of deterritorialization: the possibility of a line of flight that would allow Ryan to become-other.

Andrew made the decision to invite Ryan into the Boys with Books initiative. This invitation was based upon the Deputy's belief that there is more to any individual boy than the behaviour they display at a particular time:

When I'm talking to a kid that's disengaged, in trouble, falling out of school - you know possible disaster - I try and create a light at the end of the tunnel...they are all Homer Simpsons, you know, live in the moment - they live from pie to pie - weekend to weekend...they can't see the bigger picture so I try and create that...I develop what I can see in their personality. (Andrew)

This invitation can be understood, in the Deleuzian framework, as a key moment in Ryan's line of flight. Avolos and Winslade (2010, p. 72) argue that lines of flight "lead out of the midst of the struggle produced by a power relation to some other place; to some other territory”. This description 
resonates with the opportunity Ryan was offered: he was given a space to move beyond the oppression he was feeling within his day-to-day school experiences; and offered a chance to explore; an escape from his own daily struggle. Ryan was invited into a space that was sufficiently distant from his usual way of being at school, but also sufficiently respected by his peers to make his move into the program seem like a workable, desirable, decision.

Once this line of flight was made possible, Ryan's becoming was sustained by the nature of the connections he was able to make: particularly with the younger participants in the program. As outlined above, the structure of the sessions is simple: once a week, a group of high school boys travel to the school and (on a different day) to the alternative education setting. At their location they buddy up with one or more boys (depending on numbers in attendance on any given day). The younger boy selects a book from those that are available and then reads it to their mentor. The mentors have been provided with some simple instructions in how to support the young readers. Other than that, the older boys are mostly left to make their own decisions during the sessions: they manage the interactions in their individual ways and relate to the younger boys in equally diverse styles. In terms associated with Deleuzian perspectives on pedagogy, they are given freedom for experimentation and play (Lerner, n.d.); a scenario which also resonates with Keddie's (2006, p. 101) call for pedagogical practices underpinned by supportive classroom environments within which students have a say in the pace, and nature, of their experiences.

While shared reading is the focus of these sessions it is not all that happens. The boys also talk and laugh. The younger boys often sit upon the laps of the older boys, or hang across their shoulders. The mentors have been known to bring along guitars to play while the younger boys read (putting the words to music); to turn up in Spiderman costumes; and to generally encourage a fun and supportive environment. Because the older boys are supervised but not directed they are able to perform their role of mentor in multiple ways: ways, moreover, that make rhizomatic links between behaviours and bodies routinely kept apart.

The program gave Ryan the opportunity to work with younger boys twice each week throughout much of the school year. The sessions with the younger boys provided him with space to talk to them and read with them. More than this, the program allowed him to be both a large, physically able, Polynesian boy, and also a caring, nurturing, friendly mentor: a combination that helps to destabilise or, in Grosz's (1994, p. 181) terms "befuddle” the operations of binaries which commonly represent masculinity and femininity (and linked terms such as intellect and care; strength and affection) in oppositional relationships.

In the next section of this article we turn to consideration of what this line of flight has meant for Ryan.

\section{Becoming Ryan: perspectives from 2013}


The researchers working on this project first met Ryan three years after he first joined the program. From the beginning there seemed to be little relationship between what we had heard about Ryan's past behaviours and what we ourselves saw. Soon after her first meeting with Ryan, Mandy recorded the following observations:

I saw a very large boy who would have easily made three of my slim $160 \mathrm{~cm}$ frame. This guy was big! I am sure that without his friendly beautiful smile he was tough - but that is a side I didn't see, I only heard about it. He actually reminds me of a gentle giant. He would stride into the sessions with his grin from ear-to-ear and the younger kids' faces would light up. The smile never left his face. The kids would sit at his feet, climb all over him and he never wanted to leave. (Researcher Journal)

Initial observations, therefore, suggested that Ryan was at least in some ways a different boy in 2012, to the boy who entered the program in 2009. Insights into the nature and scope of the change that occurred are provided by Ryan, as well as his teachers, his mother and the school's leadership team. We turn to this data set in the section that follows. Before moving to discuss this material, however, there is one further point that needs to be made. Within the Deleuzian framework of becoming, a person embarked in a rhizomatic line of flight is not understood to have unequivocally rejected or separated from all their previous behaviours. Nor does it imply that they become 'new' and leave behind the 'old' or that this 'new' is a purer, more desirable subject position than where one started. Rather, tracing a line of flight is about recognising the capacity for an individual to move and to become. Through this movement the new may be connected to the old; the 'good' may be connected to 'the bad'; the present, as well, to the past. Deleuze and Guattari make all these points when they note that "any point of a rhizome can be connected to anything other, and must be” $(1987$, p. 7$)$ and that "the rhizome includes the best and the worst: potato and couchgrass, or the weed" $(1987$, p. 7).

This reminder that rhizomes are fundamentally about connections asks us to study Ryan’s becoming without looking for proof of his arrival at a new destination: rather we reflect upon his experience to look for evidence of a journey that is characterised by connections between multiple behaviours and multiple ways of being and becoming a boy-at-school.

We begin, therefore, with Ryan's own thoughts. In response to the opening question "Why is the programme important for you?” Ryan emphasised the impact of knowing he was treating the young children a particular way, making them happy and helping them read:

...because every time I go through the day I'm just like looking at - if someone who can't read - I'm just like looking at the way like I'm treating the kids...Seeing their smiles in the day - that they know how to read their book. 
Ryan's words here indicate a sense of pride and an awareness of the impact that he is having on the younger children: an impact that gives him pleasure. A sense of pleasure and enjoyment also features in Ryan's responses to other questions about the program.

Question: Do you find that you enjoy both (primary school and the alternative school)?

Ryan: $\quad$ I enjoy both. Yeah they are both good. Yeah, and they are like jumping around on me. It is so cute.

A follow up question drew attention to Ryan's enjoyment of the physical and affectionate relationship that developed between himself and the boys:

Question: $\quad$ We were saying how affectionate they are towards you guys. So do you
like that? You enjoy being that sort of figure?
Ryan: $\quad$ Yeah - like when I'm walking in the mall I see some of them and they

Question: $\quad$ Do you enjoy that?
Ryan:

When read in isolation these comments may appear relatively unremarkable. When contrasted to the earlier stories of Ryan's extreme and regular aggression—a violence that had become an almost default position-Ryan's words suggest that he has been able to move towards a space that allows for physical and verbal affection amongst boys who are, within the dominant discourses of masculinity at this school, more commonly expected to display strength and 'toughness'. In Deleuzian terms, he demonstrated a subjectivity characterised by a "series of fragments or segments...linked together in ways other than those which congeal it into an identity” (Grosz, 1993, p. 167). The pleasure Ryan appears to take from this new positioning is captured by a journal entry from one of the researchers observing a session at the alternative education setting:

This is someone that a grown adult may question saying hello to; yet here he is holding a book with a grin ear-to-ear, reading to a young buddy who is sitting with one knee up and resting his shoulder against his, listening to every word being read. (Researcher journal)

He has also “shape shifted” (MacCormack, 2001, p. 2) away from a performance of masculinity characterised by a quick temper and loss of focus towards a calmer, more moderate approach to school and sport.

Question: Do you think it's changing you at home, or at school just from being involved? 
Ryan: $\quad$ It’s changed me at both. Even umm my game, like playing rugby league - it's like changed me lots.

Question: $\quad$ Yeah, how?

Ryan: $\quad$ Like my focus and stuff, like I used to be frustrated with it - they had to like calm me down.

Ryan goes on to link this change in his ability to manage his own behaviour and his participation in the program to a change in his status within the school:

Question: $\quad$ And in school, in what way has it affected your school - like behaviour in school?

Ryan: $\quad$ Ahh everyone like treats me better now since um I'm like talking to kids, helping them read the books.

This data could be read as evidence that the teachers at the school had not been treating Ryan well originally and this is clearly not something to be ignored. However, it is more important to recognise that despite Ryan's history of violence and aggression his (past) behaviour was seen as one possible Ryan. The teachers allowed him to become another boy: to move away from being what might be seen as the dominant, arboreal "Boy" and to become-other.

Ryan has also developed a transferrable set of skills including the ability to make and sustain positive relationships. Ryan identifies different/new/positive relationships between himself and members of his family, and between himself and some other children:

Question: $\quad$ So it's been a bit of a learning curve...to be able to talk to kids...

Ryan: $\quad$ Yeah like all my nieces and nephews and stuff - they go to (my high school) - so I can handle it. Mum thinks it’s great -she loves it that I'm teaching little kids to read.

These positive relationships are seen also in Ryan's interactions with other (younger) high school students:

Question: $\quad$ There are a few Year 8 boys - this is their first year - do you feel as though they look up to you?

Ryan: $\quad$ Yeah

Question: $\quad$ Just during the programme or do you see them around school?

Ryan: $\quad$ Around school they are like giving me handshakes and stuff - and everyone is like 'how do you know him' - and they are like Boys with Books and stuff yeah. 
This strand of data raises the possibility that Ryan has been able to move away from one performance of masculinity that was individualistic, self-centred and defensive, and to explore ways of interacting with others that are regarded as calm, friendly and respectful. Through the "delicate experimentations" (Deleuze and Guattari, 1987, p. 152) made possible by Boys and Books Ryan has come to see himself as a person who is looked up to and admired: a source of admiration rather than a source of disappointment.

Ryan's comments suggest that participation in the program has provided him with increased confidence, increased happiness, and the chance to develop (possibly new) skills in building and sustaining positive relationships and that he has been able to develop the kind of "belief or trust in the world and what may yet transpire” which St.Pierre, cited earlier (2004, p. 287) links to Deleuzian affirmation. These themes are also reflected in comments made by those who have witnessed Ryan's participation in the program: his mother, his teachers and the program coordinator.

Lerner suggests that "lines of flight are creative and liberatory escapes from the standardization, oppression, and stratification of society" and “instances of thinking and acting 'outside of the box"’(Lerner, n.d. n.p.). Reflections on Ryan's experiences by those around him suggest that he has, indeed experienced some sense of liberation. Ryan's mother noted that she saw a change within a few months of joining the program: "yeah it was really quick his behaviour started to change he stopped getting suspended from school”. She goes onto describe the impact on Ryan’s confidence and selfesteem:

He feels more confidence in himself, yeah, because he knows now that he's not useless, he's not dumb. He was always told “you will not amount to anything” you know?... His whole outlook on life has changed really.

The Learning Support Teacher offered the following comments:

...I saw immediate self-esteem improvement. Work didn’t improve but his ability to relate and feel good about himself was obvious after he had been there a couple of weeks...the other teachers would come to me and say Ryan did this and I would say "Ryan this teacher told me you did this” and he would say "yeah” and so he is actually feeling good about himself.

Boys with Books founder, Andrew, also noted:

Then what I see is a confidence in him... but now there are teachers that talk about how good he is now in terms of having him in their classes. 
Happiness and enjoyment were also recurring themes. So, too, was the link between this enjoyment and a willing engagement with school. Ryan's mum said:

...it was so lovely to see him reading with little kids and actually enjoy it and wanting to go back every Wednesday you know... to the fact that he knows he has to wear correct uniform... This morning we had to go to the dryer to make sure we had the right uniform on so he could go to Boys with Books.

Ryan's teachers also noted that over the time he has participated in the program he displayed an ability not only to control his emotions, but also a willingness to share information with people, to form friendships and to trust others to deal with him respectfully. One of the most powerful examples of Ryan's growing sense of trust in others, and his willingness to move away from dominant discourses of masculinity that expect and naturalise poor communication skills and shallow relationships, is provided by his Learning Support Teacher:

Earlier in the year we were talking about emotions and I pushed all the chairs out of the road and we sat around a box with some confetti - some red shiny paper with a torch - it looks like a campfire. We switched off the lights and shut the blinds. Like a campfire we were doing stories, you know story-telling and talking about fear. He opened up and told the class about him losing his brothers and sisters and that was the first time that some of his friends really understood where he was at - he was brave... he was brave enough to open up and reveal intimate feelings that he was going through at the time...he shared those emotions...that was a real breakthrough because we were friends after that.

The scenario described by the teacher above points to one of the most significant shifts in Ryan: a rhizomatic move towards trusting-others generally and trusting-adults-at-school more specifically. This is particularly significant given literature that argues the central role that equitable teacher-student relationships can play in the pursuit of gender justice. These relationships play a key role in disrupting “traditional versions of masculinity as emotionally neutral or distant” (Keddie, 2006, p. 107): a disruption which has been particularly significant in Ryan’s journey.

One final shift in Ryan is worth noting. At the start of the program Ryan appeared like a boy whose options were already determined: exclusion, another school, exclusion, an unstable employment pathway and so on. In 2012, Ryan displayed an ability to recognise that he had choices relating both to how he would behave in various contexts, and choices about how his future would develop.

Ryan's improved ability to make choices about his behaviour are commented on by Andrew: it's not like he is a perfect student but he manages his anger better I think...you know instead of getting up and being in your face he can actually get up and say "ok I've got to leave” and he'll leave the situation... 
Ryan's belief in his future as 'open' rather than closed is also echoed by his mum who describes him as “more happier in life. He can see now he's got a direction - he didn’t have that direction before. He feels his life is worthwhile”.

Commenting on the program Ryan himself says “it’s like changed me lots” and goes onto say that now he "would like to be a mechanic or engineer" when he finishes school.

\section{Conclusion}

Literature focused on boys and schools contains important, necessary and often heart wrenching explorations of the multiple ways in which masculinity is understood and enforced within many contemporary educational contexts. As an important complement to this powerful literature Ryan's story helps to demonstrate the possibilities that exist for 'real' schools in 'real world' contexts to create opportunities for boys to embark on a line of flight that ultimately allow them to reconceptualise their relationships to school, to teachers, to peers and, indeed, to their future. Through his involvement in Boys with Books program Ryan was able to make a rhizomatic link that joined his specific past and his specific body to new sets of skills and behaviours. He was able to be big, yet gentle; strong, yet nurturing; a working class, football playing, Polynesian boy, but also a supported, respected and valued student in literacy related contexts. Perhaps above all else he is becoming a person able to make choices in how interacts with staff, students and children.

We are not seeking to represent Ryan's journey as miraculous or complete. Nor are we suggesting that the program would have the same kinds of outcomes for every participant past or present. And (although we found no evidence of this during our own time at the school), it is possible that a different analysis of the same school and the same program could uncover moments when the teachers and the boys expressed narrow, essentialist even sexist, homophobic and racist beliefs. What we do argue, however, is that Ryan's journey demonstrates the fact that even within a school that is widely seen to contain large numbers of boys aligned with narrow understandings of what it means to be a boy, it is nevertheless still possible to create spaces for lines of flight to begin.

We have argued through this paper that Ryan's journey during the Boys and Books program can be understood as a line of flight but we recognise, too, the need to be sceptical about the program's achievements. By its definition a line of flight is open, not closed. It is not possible to predict where it will end, and it is not possible to ensure that it is never reterritorialized. It is equally important to acknowledge that, in Gregoriou’s (2004, p. 243) terms the "rhizome does not have any innate subversive quality” and that a rhizomatic journey is always one of risk. Nevertheless, the literature focused on the persistence of narrow and hegemonic understandings of masculinity within Australian schools and the frequency with which interventions ultimately reinscribe these perspectives combine to remind us that boys face risks every day: both in schools that $d o$, and in schools that do not, attempt the complicated work that is gender-based educational reform. Documenting the experiences of Ryan on 
his risky, rhizomatic journey is politically significant for it demonstrates that modestly ambitious risk taking can, in fact, result in the creation of new ways for boys to experience and understand their schooling.

Commenting on the significance of lines of flight, Marcus Doel (1995) notes that:

every now and again, through the cast of the die, an event short circuits the segments, striations and codes of race, class, gender and sexuality through a becoming-clandestine, imperceptible and acategorical (p. 237)

Ryan's line of flight was sparked by this school's willingness to roll a metaphorical dice. Rather than accepting the pre-existing, molar, arboreal explanations that would account for Ryan's way of 'being' at school (and indeed, for schools' traditional ways of responding) school staff demonstrated a willingness to believe in the possibility that Ryan was in a process of becoming. Ryan's school made the decision to see what would happen if he and other boys were given opportunities to move beyond familiar performances of masculinity. By providing institutionally legitimated spaces for diverse boys to interact with smaller, younger, vulnerable children, the Boys with Books program opened up possibilities for all of the mentors to 'be' at school in different ways. Most importantly, this commitment to recognising that the boys were becoming (not just being) sparked a remarkable journey for Ryan: a journey that allowed him to conclude that for now, at least sometimes, life is “all right”.

\section{Acknowledgments}

The research would not have been possible without the generous support of the staff who worked on the Boys with Books initiative and the inspiration of the project leader. We thank them for their time and enthusiasm and for trusting us enough to allow us into their worlds for such a sustained amount of time. Most of all we thank all of the participants who took part in the research, particularly the boys and their families. Without their generosity, openness and willingness to talk the research would clearly not have been possible.

We would also like to thank Chris Bigum and Catherine Beavis for their feedback on earlier drafts of this paper. Their advice and support was, as always, insightful, generous and fundamentally enabling.

\section{References}

Alloway, N., \& Dalley-Trim, L. (2006). Success for boys: Boys and literacy module. Canberra: Curriculum Corporation.

Alloway, N., Freebody, P., Gilbert, P., \& Muspratt, S. (2002). Boys, literacy and schooling: Expanding the repertoire of practice. Canberrra: Commonwealth of Australia, Department of Education, Science and Training.

Archer, L., \& Yamashita, H. (2003). Theorising innter-city maculinities: 'Race', class, gender and education. Gender and Education, 15(2), 115-132. doi:10.1080/09540250303856. 
Avolos, M., \& Winslade, J. (2010). Education as a 'line of flight'. Explorations: An Ejournal of Narrative Practice, 1, 70-77.

Bogue, R. (2002). Deleuze and Guattari. London: Routledge.

Braidotti, R. (1994). Nomadic subjects: Embodiment and sexual difference in contemporary feminist theory. New York: Columbia University Press.

Brozo, W. (2006). Bridges to literacy for boys. Educational Leadership, September, 71-74.

Collins, C., Kenway, J., \& McLeod, J. (2000). Factors influencing the educational performance of males and females in school and their initial destinations after leaving school. Canberra: Commonwealth Department of Education, Training and Youth Affairs.

Connell, R. W. (1996). Teaching the boys: New research on masculinity, and gender strategies for schools. Teachers College Record, 98(2), 206-235.

Davies, B. (1994). Poststructuralist theory and classroom practice. Geelong: Deakin University Press.

Deleuze, G., \& Guattari, F. l. (1987). A thousand plateaus: Capitalism and schizophrenia. Minneapolis: University of Minnesota Press.

Deleuze, G., \& Parnet, C. (1987). Dialogues. New York: Columbia University Press.

Doel, M. (1995). Bodies without organs: Schizoanalysis and deconstruction. In S. Pile, \& N. Thrift (Eds.), Mapping the subject: Geographies of cultural production (pp. 226240). London: Routledge.

Gilbert, R., \& Gilbert, P. (1998). Masculinity goes to school. Allen and Unwin: St Leonards, NSW.

Giroux, H. A. (2003). Public time and educated eope: Educational leadership and the war against youth.Retrieved from http://www.units.muohio.edu/eduleadership/anthology/OA/OA03001.html. Accessed 22 November 2013.

Gregoriou, Z. (2004). Commencing the rhizome: Towards a minor philosophy of education. Educational Philosophy and Theory, 36(3), 233-251. doi:10.1111/j.1469-5812.2004.00065.x.

Griffin, J. (1994). The SchoolWatch report: A study into anti-lesbian and anti-gay harassment and violence in Australian schools. Sydney: J. Griffin.

Grosz, E. (1993). A thousand tiny sexes: Feminism and rhizomatics. Tapoi, 12, 167-179.

Grosz, E. (1994). Volatile bodies: Towards a corporeal feminism. Bloomington, Indiana: Indiana University Press.

Gurian, M. (2001). Boys and girls learn differently: A guide for teachers and parents. San Francisco: Jossey-Bass.

Hayes, D., Mills, M., Christie, P., \& Lingard, B. (2006). Teachers and schooling: Making a difference. Sydney: Allen \& Unwin.

Jones, A. (1997). Teaching post-structural theory in education: Student resistances. Gender and Education, 9(3), 261-269. doi:10.1080/09540259721240.

Keddie, A. (2003). On leadership and fitting in: Dominant understandings of masculinities within an early primary peer group. The Australian Educational Researcher, 30(1), 83-100. doi:10.1007/BF03216782.

Keddie, A. (2005). A framework for gender justice: Evaluating the transformative capacities of three key Australian schooling initiatives. The Australian Educational Researcher, 32(3), 83-102. doi:10.1007/BF03216828.

Keddie, A. (2006). Pedagogies and critical reflection: Key understandings for transformative gender justice. Gender and Education, 18(1), 99-114. doi:10.1080/09540250500195184.

Keddie, A. (2008). Playing the game: Critical literacy, gender justice and issues of masculinity. Gender and Education, 20(6), 571-583. doi:http://dx.doi.org/10.1080/09540250701829979. 
Kehler, M. D. (2007). Hallway fears and high school friendships: The complications of young men (re)negotiating heterosexualized identities. Discourse, 28(2), 259277. doi:10.1080/01596300701289375.

Kenway, J., Willis, S., Blackmore, J., \& Rennie, L. (1994). Making 'hope practical' rather than 'despair convincing': Feminist post-structuralism, gender reform and educational change. British Journal of Sociology of Education, 15(2), 187-210. doi:10.1080/0142569940150203.

Lerner, J. (n.d.). About lines of flight. Retrieved from http://www.linesofflight.net/linesofflight.htm Accessed 12 March 2013.

Lingard, B., \& Douglas, P. (1999). Men engaging feminisms: Profeminism, backlashes and schooling. Buckingham, UK: Open University Press.

Mac an Ghaill, M. (1994). The making of men. Buckingham, England: Open University Press.

MacCormack, P. (2001). Becoming hu-man: Delezue and Guatarri, Gender and 3rd Rock from the Sun. Intensities: The Journal of Cult Media, 1(4), 1-15.

Major, J., \& Santoro, N. (2014). 'Sensible girls' and 'silly boys': what do teachers need to know about gender? The Australian Educational Researcher, 41(4), 59-72. doi:10.1007/s13384-013-0121-0.

Martino, W., Kehler, M., \& Weaver-Hightower (2009). Preface. In W. Martino, M. Kehler, \& Weaver-Hightower (Eds.), The problem with boys' education: Beyond the backlash (pp. xii-xx). New York: Routledge.

Martino, W., Lingard, B., \& Mills, M. (2004). Issues in boys' education: A question of teacher threshold knowledges? Gender and Education, 16(4), 435-454. doi:10.1080/09540250042000300367.

Martino, W., \& Pallotta-Chiarolli, M. (2005). 'Being normal is the only way to be': Boys and adolescent perspectives on gender and school. Sydney: UNSW Press.

Newkirk, T. (2000). Misreading masculinity: Boys, literacy and popular culture. Portsmouth, NH: Heinemann.

Ontario Ministry of Education (n.d.). Me Read? No Way! A practical guide to improving boys' literacy skills. Calgary: Ontario Ministry of Education.

Organisation for Economic Co-operation and Development (2004). Messages from PISA 2000. Paris: OECD Publications.

Rothman, S., \& McMillan, J. (2003). Influences on achievement in literacy and numeracy. Longitudinal surveys of Australian youth. Camberwell, Victoria: Australian Council for Educational Research.

Rowan, L., Knobel, M., Bigum, C., \& Lankshear, C. (2002). Boys, literacies, and schooling: The dangerous territories of gender-based literacy reform (Educating boys, learning gender). Buckingham, England: Open University Press.

Rowan, L., \& Lynch, J. (2011). The continued underrepresentation of girls in postcompulsory information technology courses: A direct challenge to teacher education. Asia-Pacific Journal of Teacher Education, 39(2), 83-95. doi:10.1080/1359866X.2011.560650.

Sommers, C. H. (2000a). The war against boys.Retrieved from http://www.theatlantic.com/magazine/archive/2000/05/the-war-againstboys $/ 304659 /$. Accessed 12 January 2014.

St.Pierre, E. A. (2004). Deleuzian concepts for education: The subject undone. Educational Philosophy and Theory, 36(3), 283-296. doi:10.1111/j.14695812.2004.00068.x.

Taylor, D., \& Lorimer, M. (2002/2003). Helping boys succeed. Educational Leadership, $60(4), 68-70$.

Titus, J. J. (2000). Engaging student resistance to feminism: 'How is this stuff going to make us better teachers?'. Gender and Education, 12(1), 21-37. doi:10.1080/09540250020382. 
Weedon, C. (1987). Feminist practice and poststructural theory. Oxford, UK: Basil Blackwell.

White, B. (2007). Are girls better readers than boys? Which boys? Which girls? Canadian Journal of Education, 30(2), 554-581.

\section{Author Biographies}

Mandy Rogers has recently graduated with a Bachelor of Education (Honours, $1^{\text {st }}$ Class) from Griffith University. Her honours research focused on the Boys and Books project explored in this paper.

Leonie Rowan is an Associate Professor in the School of Education and Professional Studies at Griffith University. Her research interests relate primarily to the social contexts of education, gender, feminist theory, and the multiple ways in which educators in schools, universities and other learning environments can meet the needs of diverse student populations.

Rachel Walker has recently graduated with a Bachelor of Education (Honours, $1^{\text {st }}$ Class) from Griffith University. Her honours research focused on the Boys and Books project explored in this paper. 